\section{Zie mij}

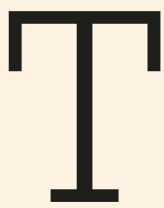

ijdens je stage kunnen je

werkbegeleider en collega's je carrière maken of bre-

ken. Ik weet er alles van. Ik deed de opleiding hbo-v

duaal in een academisch ziekenhuis.

Mijn eerste begeleider was ronduit fantastisch. De basis van het vak heb ik van hem geleerd en daar ben ik hem nog altijd dankbaar voor. Maar daarna ging het mis. Aanvankelijk vol zelfvertrouwen trof ik een afdeling waar ik - naar mijn mening - niet gezien werd, en knapte ik volledig af op de zorg. Ik verliet het ziekenhuis en maakte de opleiding af in deeltijd. Toch wilde ik niet in de directe patiëntenzorg blijven werken. Dus werd ik - kort samengevat - hoofdredacteur van Nursing. De zorg heeft mij destijds als nieuwbakken verpleegkundige dus niet kunnen behouden.

En ik was en ben niet de enige. Heel wat stagiaires hebben het gevoel dat ze te weinig begeleid worden, wat sommigen doet afhaken. Dat blijkt uit een studie van NU'91. De vakbond deed onlangs een online 'zorgstagecheck', waaraan 887 stagiaires in de zorg deelnamen, voornamelijk stagiaires verpleegkunde. Bijna 60 procent had meer begeleiding gewild, vooral in het durven opkomen voor het eigen leerproces, het bewaken en aangeven van grenzen en bij het zoeken naar de juiste vaktechnische informatie.

Dit komt overeen met hetgeen onderzoekster Yvonne ten Hoeve van de Rijksuniversiteit Groningen jaren geleden al tegenkwam. $Z$ ij vroeg verpleegkundestudenten naar hun driifveren om verpleegkunde te studeren. Wat bleek? Indien ze overwogen om af te haken, dan had dit steeds te maken met ervaringen waarbij ze een gebrek aan steun ervaren hadden. Omgekeerd was de factor om het wél vol te houden erg duidelijk: het gevoel verwelkomd te worden in een aangenaam team.
Er zijn allerlei excuses te verzinnen om leerlingen niet optimaal te kunnen begeleiden, waarvan te weinig personeel waarschijnlijk de meest gehoorde is. Maar het gevoel niet welkom te zijn is zó iets basaals. Hoe is het toch mogelijk dat stagiaires niet overal altijd welkom zijn? Natuurlijk moet je energie steken in de begeleiding, maar het levert - zeker op de lange termijn - zoveel op! Ik weet dat niet iedere verpleegkundige het talent heeft om een goede studentenbegeleider te zijn. En dat hoeft ook niet, maar dan is het aan de afdeling om begeleiders te koppelen die dat wel kunnen. En willen vooral.

In het artikel over de begeleiding van stagiaires op pagina 18 , valt op dat maatwerk de rode draad is van goede begeleiding. Dat bevestigt ook Monique Mooijes, praktijkopleider in het ETZ TweeSteden ziekenhuis in Tilburg. 'Bij binnenkomst kan je iedereen op hetzelfde punt laten beginnen', zegt zij. 'Van daaruit gaat de individuele student zich ontwikkelen, ieder op zijn specifieke manier en op zijn eigen tempo.' Ik geloof hier ook in, al vraagt het om veel flexibiliteit van het team en de vaste begeleider.

Terugkomend op mijn persoonlijke ervaring is dat verpleegkundigen het vaak lastig vinden als je harder loopt dan je leerdoelen of passend bij je opleiding en ervaring. Ik kan niet zo goed verklaren waar dat aan ligt. Ik denk dat veel verpleegkundigen hun leerlingen te veel willen beschermen. Maar daar is nog nooit iemand van gegroeid. En dan 'zie' je je student ook niet echt. Wie weet hoe het was gelopen als ik mij destijds wat meer gezien had geweten. Ach, ik heb daar ook van geleerd. En zie mij hier nu eens staan; het is allemaal goed gekomen.

\section{Alexia Hageman}

\section{Hoofdredacteur Nursing}

Alexia.Hageman@bsl.nl

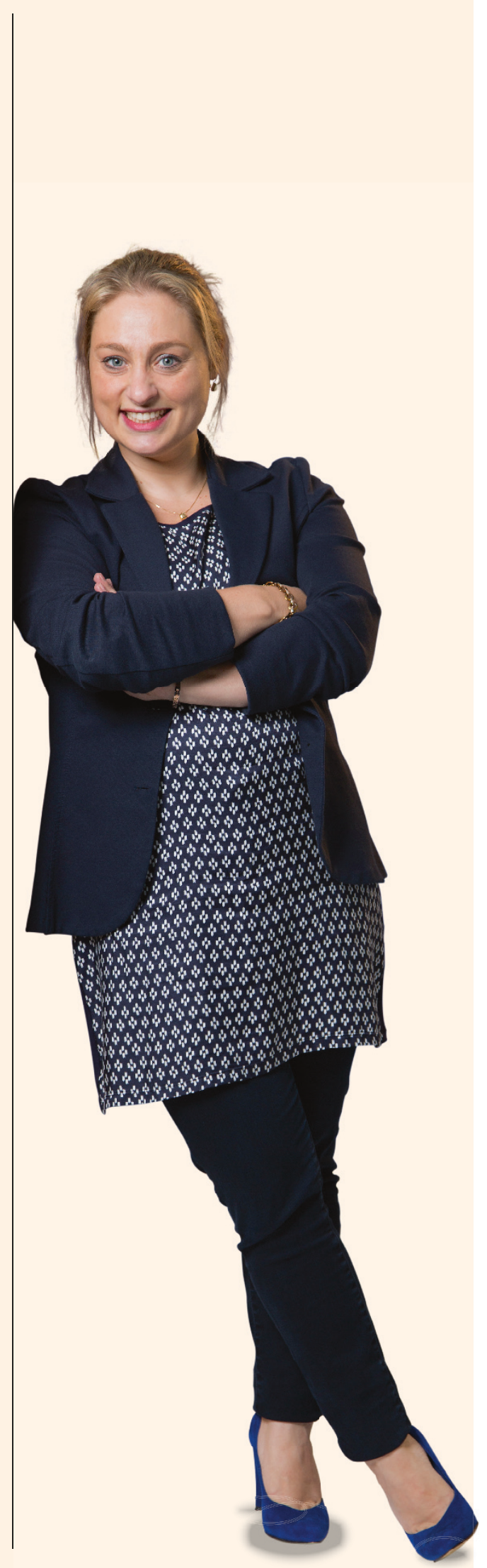

juli/augustus 2018 | nursing 